\title{
VIII FUJIFILM
}

I\&I-Imaging \& Information

\section{Х線画像情報のデジタル化により医用画像の一元管理を実現する \\ FUJI COMPUTED RADIOGRAPHY}

FUJI E-DMSネットワーク

Expanding

-高画質で安定した診断画像の提供。

豊富なラインアップで診断目的に合わせたシステムの構筑および拡張が自在。

-FCRやCT・MRIなど各種診断画像・情報を一括して光ディスクに保管、画像の一元管理を実現。

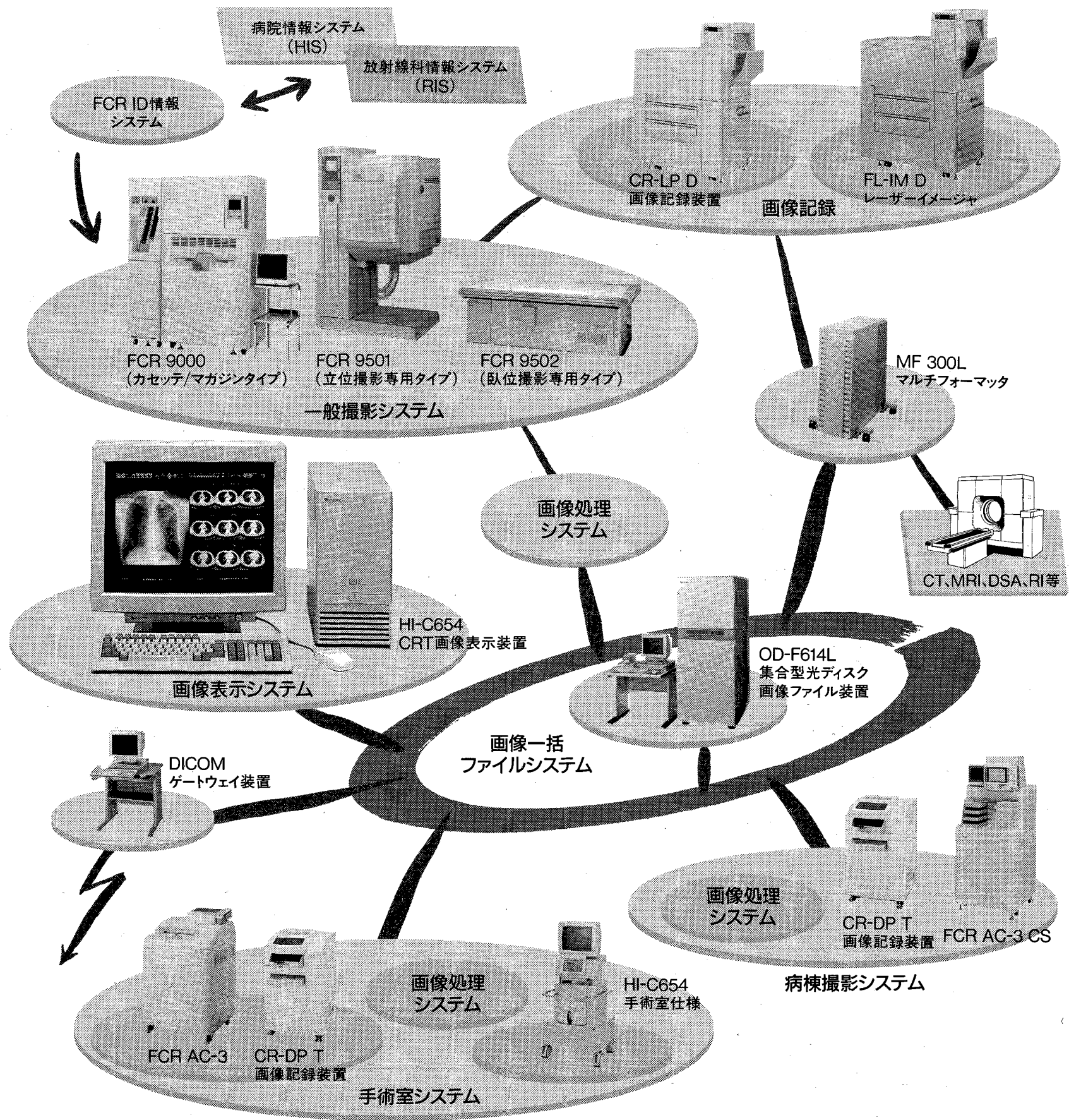

